人類喆. J. Anthrop. Soc. Nippon

人9 (1): $85-98$ (1981)

\title{
Growth of the Second Metacarpal in Hottentots
}

\author{
Ronald SINGER ${ }^{1)}$ and Kunihiko KIMURA ${ }^{2) *}$ \\ 1) Department of Anatomy, The University of Chicago \\ 2) Department of Anatomy, National Defense Medical College
}

\begin{abstract}
On the basis of the chronological and TW2 skeletal ages, increase in length and width and age changes in the width/length index of the second metacarpal are discussed for 49 male and 61 female Hottentot children aged 3 to 17 years from Warmbad, Namibia and 124 boys and 113 girls aged 1 to 21 years of related populations, the Rehoboth Basters of Namibia and Cape Coloreds from Cape Town, South Africa. The results are mainly compared with data for American Blacks and Whites, as well as for Japanese. Based on skeletal age, both metacarpal length and width are similar in all the populations until a critical point is reached, when the rate of increase becomes different for each. Thereafter, these bone dimensions are greater in the Rehoboth Basters than in the Hottentots and Japanese. However, comparisons of the index of width relative to the length of the second metacarpal at maturity show that the Hottentots, as well as their related populations, seem to be similar to the American Blacks and Whites, but slightly lower than the Japanese.
\end{abstract}

\section{INTRODUCTION}

Body height and weight are positively correlated with dimensions of tubular bones (REYNOLDS, 1944; MARESH, 1961; Mazess and Cameron, 1971; Himes, MALINA and STEPICK, 1976), and the sex differences in bone dimensions are primarily the result of differences in body size (OWen, Filer, Maresh and Fomon, 1966 ; Wolański, 1967 ; Himes, Martorell, HABICHT, YARBROUGH, MALINA and Klein, 1976 ; Himes and Malina, 1977). However, in the second metacarpal of Japanese chil-

* Visiting Research Associate and Professorial Lecturer, The University of Chicago, 1974-1975, 1977, 1979

Article No. 8006 dren, Kimura (1976 and 1977) has suggested that, on the basis of skeletal maturity, the growth curve for bone length is almost parallel in both boys and girls, while that for bone width follows this pattern until about adolescence, whereafter it increases more rapidly in boys than in girls. Thus, the mean values of bone length and width are always greater in boys than in girls, though the sex difference of the latter becomes greater after adolescence. The present study is part of a survey of the biology of the Hottentots of Namibia (South West Africa): see SINGER and WeINER (1963); KRUT and Singer (1963); Weiner, Harrison, Singer, Harris and JOPP (1964); SINGER (1970); HELTNE and 
Singer (1971); Singer and Gajisin(1974); Kimura and Singer (1979); and Singer, Kimura and Gajisin (1980). In this paper, growth of bone length and width and age changes of the index of width/ length in the second metacarpal of Hottentot, Rehoboth Baster and Cape Colored children are evaluated on the basis of both chronological and TW2 skeletal ages. The results are mainly compared with those for American Whites and Blacks (GARN, Miller and LARSON, 1972), as well as for Japanese (KIMURA, 1976 and unpublished). Comparable data are not available for southern African White and Black populations, while the Japanese data represent an Asian, genetically short and medium height population.

\section{MATERIALS AND METHODS}

The African sample comprised 110 Nama-speaking Hottentot children (49 boys and 61 girls) aged 3 to 17 years at Warmbad, Namibia, 196 children of the Rehoboth Basters (110 boys and 96 girls) aged 6 to 21 years in Rehoboth, Namibia and 41 children of Cape Coloreds (24 boys and 17 girls) aged 1 to 6 years from Bonnytoun School near Cape Town, South Africa. The Rehoboth Basters and Cape Coloreds are essentially Hottentot-White admixtures, though their individual histories vary (WEINER et al, 1964). The data were collected by SINGER in 1961. In addition, in 1964, 15 boys and 24 girls of the Hottentots in Warmbad were reinvestigated for growth changes. Radiographs of the left hand and wrist were taken at an anode-film distance of $75 \mathrm{~cm}$ with the tube centered above the head of the third metacarpal. Bone length and width at mid-shaft were measured on $x$-ray films with a sliding caliper accurate to $0.1 \mathrm{~mm}$. In addition, the index of bone width to bone length (W/L) was calculated from these measurements. For assessing skeletal maturity the TW2 method (Tanner, Whitehouse, Marshall, Healy and Goldstein, 1975) was used with the 20-bones scores. On all the samples of the Hottentots, Rehoboth Basters, Cape Coloreds and Japanese, the measurements of the second metacarpal and the assessment of skeletal maturation were made by KimURA. For age-grouping, the midage method was used, for example, the 7 years age class contained the children aged from 6.50 through 7.49 years at the date of investigation in both chronological and skeletal ages. Accurate chronological age is not always known for every individual in anthropological investigations. In this study, data of a few individuals whose chronological ages were excessively divergent from their skeletal ages were excluded from the analysis. The t-test was applied to examine the significance of the differences of measurements and indices between sexes and between populations. However, because of the unavoidably small sample sizes of the Hottentots and their related populations, all individuals were plotted in the graphs.

\section{RESULTS AND DISCUSSION}

The means $(\bar{x})$ and standard deviations (S. D.) of bone length and width and of 
Table 1. Means $(\overline{\mathbf{x}})$ and standard deviations (S. D.) of the measurements ( $\mathrm{mm}$ ) of the second metacarpal in the Hottentot children for each chronological age class.

\begin{tabular}{|c|c|c|c|c|c|c|c|c|c|c|c|c|}
\hline \multirow[b]{2}{*}{ Sex } & \multirow[b]{2}{*}{ Class } & \multirow[b]{2}{*}{$\mathrm{n}$} & \multicolumn{2}{|c|}{ Chron. age } & \multicolumn{2}{|c|}{ TW2 age } & \multicolumn{2}{|c|}{ Length } & \multicolumn{2}{|c|}{ Width } & \multicolumn{2}{|c|}{$\mathrm{W} / \mathrm{L}$} \\
\hline & & & $\bar{x}$ & S. D. & $\bar{x}$ & S. D. & $\bar{x}$ & S. D. & $\bar{x}$ & S. D. & $\bar{x}$ & S. D. \\
\hline \multirow{12}{*}{$\stackrel{\infty}{\stackrel{0}{0}}$} & 3 & 1 & 3.0 & - & 2.1 & - & 30.2 & - & 4.8 & - & 15.9 & - \\
\hline & 7 & 2 & 7.0 & 0.28 & 3.8 & 0.07 & 33.9 & 1.84 & 4.9 & 1.14 & 14.5 & 1.20 \\
\hline & 8 & 6 & 8.8 & 0.35 & 6.6 & 1.69 & 41.9 & 2.65 & 5.2 & 0.56 & 12.4 & 0.96 \\
\hline & 9 & 2 & 9.2 & 0.00 & 8.4 & 1.20 & 42.6 & 0.57 & 6.0 & 0.00 & 14.1 & 0.14 \\
\hline & 10 & 4 & 10.0 & 0.35 & 8.0 & 1.85 & 42.1 & 4. 29 & 5.7 & 0.29 & 13.5 & 1.49 \\
\hline & 11 & 10 & 10.9 & 0.28 & 9.3 & 1.55 & 46.5 & 2.34 & 6.1 & 0.67 & 13.2 & 1.27 \\
\hline & 12 & 3 & 12.0 & 0.40 & 10.4 & 1.25 & 46.5 & 2.97 & 6.9 & 0.40 & 14.8 & 0.25 \\
\hline & 13 & 7 & 12.8 & 0.15 & 10.7 & 1.86 & 47.3 & 4.04 & 6.3 & 0.81 & 13.3 & 1.89 \\
\hline & 14 & 5 & 14.0 & 0.26 & 12.7 & 1.91 & 53.9 & 2.28 & 7.2 & 0.63 & 13.4 & 1.15 \\
\hline & 15 & 2 & 15.0 & 0.50 & 13.5 & 2.33 & 55.2 & 2.33 & 6.9 & 0.14 & 12.6 & 0.78 \\
\hline & 16 & 3 & 15.9 & 0.10 & 14.9 & 0.40 & 53.9 & 1.33 & 6.9 & 0.93 & 12.9 & 2.09 \\
\hline & 17 & 2 & 16.9 & 0.07 & 14.9 & 0.50 & 58.8 & 4.67 & 7.4 & 0.92 & 12.5 & 0.50 \\
\hline \multirow{11}{*}{ 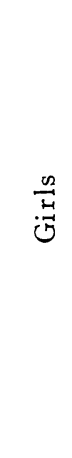 } & 7 & 2 & 7.0 & 0.35 & 5.6 & 0.21 & 39.2 & 0.92 & 5.1 & 0.14 & 13.1 & 0.64 \\
\hline & 8 & 7 & 8.1 & 0.30 & 7.3 & 1.23 & 42.6 & 2.83 & 5.3 & 0.43 & 12.4 & 1.35 \\
\hline & 9 & 2 & 8.7 & 0.14 & 8.9 & 0.28 & 50.4 & 5.02 & 6.5 & 0.71 & 12.9 & 0.14 \\
\hline & 10 & 7 & 9.9 & 0.21 & 9.5 & 2.08 & $\nabla 48.4$ & 5.69 & $\nabla 6.2$ & 0.56 & $\nabla 12.7$ & 0.92 \\
\hline & 11 & 10 & 11.1 & 0.31 & 9.3 & 1.20 & $\nabla 45.7$ & 1.82 & $\nabla 6.0$ & 0.43 & $\nabla 13.2$ & 1.01 \\
\hline & 12 & 6 & 12.1 & 0.39 & 10.4 & 1.80 & 48.9 & 6.73 & 6.1 & 1.00 & 12.4 & 0.71 \\
\hline & 13 & 8 & 12.9 & 0.24 & 11.2 & 1.87 & 51.9 & 4.29 & 6.6 & 0.81 & 12.8 & 2.28 \\
\hline & 14 & 8 & 14.0 & 0.38 & 13.0 & 0.28 & 53.5 & 3.71 & 6.9 & 0.48 & 12.9 & 1.09 \\
\hline & 15 & 4 & 15.1 & 0.34 & 13.4 & 0.73 & 52.6 & 3.66 & 6.5 & 0.42 & 12.4 & 0.40 \\
\hline & 16 & 4 & 16.0 & 0.30 & 14.2 & 1.16 & 58.8 & 3.90 & 6.8 & 0.61 & 11.7 & 1.90 \\
\hline & 17 & 3 & 16.8 & 0.29 & 15.2 & 0.97 & 59.0 & 6.44 & 7.3 & 0.55 & 12.3 & 1.00 \\
\hline
\end{tabular}

Note: $\nabla 10$ yrs. $\mathrm{n}=6 ; \nabla 11$ yrs. $\mathrm{n}=9$

the index of width/length of the second metacarpal in the Hottentots, Rehoboth Basters and Cape Coloreds are given in Tables 1 to 3 for each chronological age class and in Tables 4 to 6 for each TW2 skeletal age class. The results of the t-test are shown in Table 7 by single $(P \leqq 0.05)$ and double $(\mathrm{P} \leqq 0.01)$ asterisks for the differences between sexes, and also populations. Figures 1 and 2 show the growth of bone length and width, and Figure 3 the age changes of the index of width/ length, plotted against each skeletal (up- per) and chronological (lower) age class for the Hottentots and Rehoboth Basters, compared with those for the American Whites and Blacks, as well as those for the Japanese for reference.

On the basis of chronological age, there are few significant sex differences for both bone length and width in both Hottentots and the related populations through almost all the recorded ages, except for the ages of 17 years for the length and of 16 and 17 years for the width in the Rehoboth Basters. In general, the bone 
Table 2. Means ( $\bar{x}$ ) and standard deviations (S. D.) of the measurements ( $m m$ ) of the second metacarpal in the children of Rehoboth Basters for each chronological age class.

\begin{tabular}{|c|c|c|c|c|c|c|c|c|c|c|c|c|}
\hline \multirow[b]{2}{*}{ Sex } & \multirow[b]{2}{*}{ Class } & \multirow[b]{2}{*}{$\mathrm{n}$} & \multicolumn{2}{|c|}{ Chron. age } & \multicolumn{2}{|c|}{ TW2 age } & \multicolumn{2}{|c|}{ Length } & \multicolumn{2}{|c|}{ Width } & \multicolumn{2}{|c|}{$\mathrm{W} / \mathrm{L}$} \\
\hline & & & $\bar{x}$ & S. D. & $\bar{x}$ & S. D. & $\bar{x}$ & S. D. & $\bar{x}$ & S. D. & $\bar{x}$ & S. D. \\
\hline \multirow{15}{*}{ के } & 7 & 2 & 7.0 & 0.00 & 6.1 & 0.99 & 40.1 & $* 0.35$ & 5.9 & 0.64 & 14.6 & 1.70 \\
\hline & 8 & 12 & 8.0 & 0.07 & 7.6 & 1.17 & 46.5 & $* 2.55$ & 6.2 & $* 0.58$ & 13.5 & 1.29 \\
\hline & 9 & 7 & 9.0 & 0.08 & 9.0 & 1.37 & 47.2 & 3.34 & 6.5 & 0.63 & 13.8 & 1.57 \\
\hline & 10 & 4 & 10.0 & 0.00 & 8.7 & 1.41 & 47.2 & 2.45 & 6.4 & 0.56 & 13.7 & 1.78 \\
\hline & 11 & 8 & 11.0 & 0.00 & 11.0 & $* 1.23$ & 53.5 & $* 3.54$ & 7.0 & $* 0.61$ & 13.2 & 1.35 \\
\hline & 12 & 4 & 12.1 & 0.15 & 9.9 & 1.36 & 50.4 & 3.41 & 7.0 & 0.57 & 13.9 & $* 0.50$ \\
\hline & 13 & 11 & 13.0 & 0.09 & $\triangle 12.3$ & 1.40 & 55.9 & *3. 49 & 7.5 & ${ }^{*} 0.85$ & 13.4 & 1.55 \\
\hline & 14 & 7 & 14.0 & 0.00 & $\triangle 13.5$ & 1.34 & 57.6 & 3.57 & 8.0 & $* 0.58$ & 13.9 & 1.10 \\
\hline & 15 & 8 & 15.0 & 0.07 & 14.2 & 1.48 & 60.0 & 6.96 & 7.9 & 0.66 & 13.2 & 1.30 \\
\hline & 16 & 10 & 16.0 & 0.06 & 15.7 & 0.96 & 66.5 & $* 4.54$ & 8.7 & $* 0.69$ & 13.0 & 0.96 \\
\hline & 17 & 10 & 17.0 & 0.09 & 16.4 & $* 0.88$ & 68.5 & $* 3.26$ & 9.3 & ${ }^{*} 0.83$ & 13.6 & 1.32 \\
\hline & 18 & 7 & 18.0 & 0.08 & 17.2 & 1.07 & 68.5 & 3.13 & 8.5 & 1.00 & 12.5 & 1.22 \\
\hline & 19 & 6 & 19.0 & 0.07 & 17.6 & 0.70 & 70.6 & 4.22 & 8.8 & 0.99 & 12.6 & 1.80 \\
\hline & 20 & 3 & 19.9 & 0.12 & 18.0 & 0.00 & 69.8 & 3.51 & 9.4 & 0.52 & 13.5 & 0.76 \\
\hline & 21 & 1 & 21.0 & - & 18.0 & - & 74.4 & - & 9.4 & - & 12.6 & - \\
\hline \multirow{13}{*}{$\underset{\mathscr{B}}{\stackrel{\infty}{B}}$} & 6 & 1 & 6.2 & - & 6.7 & - & 41.5 & - & 5.9 & - & 14.2 & - \\
\hline & 8 & 8 & 8.0 & 0.14 & 8.0 & 1.18 & 46.3 & 5.19 & 6.0 & 0.85 & 13.0 & 1.26 \\
\hline & 9 & 8 & 9.0 & 0.00 & 9.0 & 1.41 & 48.2 & 3.71 & 6.4 & 0.57 & 13.2 & 1.03 \\
\hline & 10 & 7 & 10.0 & 0.11 & 9.8 & 1.04 & 51.9 & 6.09 & 6.8 & 0.77 & 13.1 & 0.67 \\
\hline & 11 & 12 & 11.0 & 0.09 & 10.5 & 1.55 & $\nabla 52.0$ & $* 2.78$ & $\nabla 6.9$ & $* 0.66$ & $\nabla 13.3$ & 1.15 \\
\hline & 12 & 12 & 12.0 & 0.09 & 11.2 & 1.85 & 53.1 & 5.83 & 6.8 & 0.72 & 12.8 & 1.34 \\
\hline & 13 & 9 & 12.9 & 0.10 & 12.3 & 1.11 & 56.0 & 4.51 & 7.5 & $* 0.67$ & 13.4 & 1.59 \\
\hline & 14 & 12 & 14.0 & 0.00 & 13.4 & 0.65 & 60.4 & $* 4.75$ & 7.5 & $* 0.61$ & 12.4 & 0.99 \\
\hline & 15 & 9 & 15.0 & 0.06 & $\nabla 13.8$ & 1.45 & 63.8 & $* 4.10$ & 7.9 & $* 0.70$ & 12.5 & 1. 10 \\
\hline & 16 & 5 & 16.0 & 0.09 & 15.5 & 0.51 & 63.3 & 2.82 & 7.8 & $* 0.57$ & 12.4 & 1.21 \\
\hline & 17 & 7 & 16.9 & 0.10 & 16.0 & $* 0.07$ & 64.0 & 2.62 & 7.6 & 0.35 & 11.9 & 0.83 \\
\hline & 18 & 5 & 18.0 & 0.09 & 16.0 & 0.00 & 65.7 & 3.95 & 7.8 & 0.76 & 11.9 & 0.81 \\
\hline & 19 & 1 & 19.0 & - & 16.0 & - & 63.3 & - & 7.4 & - & 11.7 & - \\
\hline
\end{tabular}

Note: $\triangle 13$ yrs. $n=10 ; \triangle 14$ yrs. $n=6$

$\nabla 11$ yrs. $\mathrm{n}=11$

length and width are significantly greater in the Rehoboth Basters than in the Hottentots for both sexes. In both bone length and width, the American Blacks show the greatest, followed by the American Whites, and the Hottentots the smallest values among the five populations through almost all the ages. However, after adolescence, the rate of increas is certainly seen for both length and width between greater in the Hottentots (with some uncertainty for the males) and Rehoboth Basters than in the other populations. Then the Rehoboth Basters considerably surpass the Japanese and approach the American Whites, while the Hottentots approach the Japanese soon afterwards. Significant racial differences are generally 
Table 3. Means $(\bar{x})$ and standard deviations (S.D.) of the measurements ( $\mathrm{mm}$ ) of the second metacarpal in the children of Bonnytoun for each chronological age class.

\begin{tabular}{|c|c|c|c|c|c|c|c|c|c|c|c|c|}
\hline \multirow[b]{2}{*}{ Sex } & \multirow[b]{2}{*}{ Class } & \multirow[b]{2}{*}{$\mathrm{n}$} & \multicolumn{2}{|c|}{ Chron. age } & \multicolumn{2}{|c|}{ TW2 age } & \multicolumn{2}{|c|}{ Length } & \multicolumn{2}{|c|}{ Width } & \multicolumn{2}{|c|}{$\mathrm{W} / \mathrm{L}$} \\
\hline & & & $\overline{\mathrm{x}}$ & S. D. & $\overline{\mathrm{x}}$ & S. D. & $\overline{\mathrm{x}}$ & S. D. & $\overline{\mathrm{x}}$ & S. D. & $\overline{\mathrm{x}}$ & S. D. \\
\hline \multirow{6}{*}{ 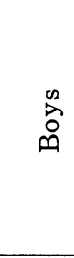 } & 1 & 1 & 1.5 & - & & & 24.2 & - & 4.2 & - & 17.4 & - \\
\hline & 2 & 4 & 2.4 & 0.25 & 2.0 & 0.59 & 28.1 & 2.44 & 4.3 & 0.53 & 15.1 & 1.21 \\
\hline & 3 & 7 & 3.2 & 0.24 & 2.5 & 0.84 & $\triangle 30.5$ & 2.42 & $\triangle 4.9$ & 0.39 & $\triangle 16.0$ & 1.66 \\
\hline & 4 & 6 & 4.2 & 0.26 & $\triangle 3.9$ & 1.27 & 35.4 & 2.99 & 5.1 & 0.51 & 14.3 & 0.66 \\
\hline & 5 & 3 & 5.1 & 0.17 & $\triangle 3.8$ & - & 36.0 & 2.72 & 4.8 & 0.50 & 13.4 & 2.41 \\
\hline & 6 & 3 & 6.0 & 0.00 & $\triangle 6.6$ & - & $\triangle 40.0$ & 1.41 & $\triangle 5.8$ & 0.42 & $\triangle 14.5$ & 0.57 \\
\hline \multirow{5}{*}{$\stackrel{\infty}{D}$} & 1 & 1 & 1.5 & - & 1.4 & - & 27.5 & - & 4.5 & - & 16.4 & - \\
\hline & 2 & 3 & 2.2 & 0.29 & $\nabla 1.3$ & 0.42 & 29.8 & 3.48 & 4.2 & 0.62 & 14.4 & 3.93 \\
\hline & 3 & 3 & 3.1 & 0.38 & $\nabla 2.0$ & - & 33.8 & 2.72 & 4.7 & 0.64 & 13.8 & 1.25 \\
\hline & 4 & 5 & 4.2 & 0.27 & $\nabla 4.6$ & - & 36.5 & 1.21 & 5.3 & 0.59 & 14.6 & 1.82 \\
\hline & 5 & 5 & 5.2 & 0.03 & $\nabla 3.6$ & - & 37.9 & 2.39 & 5.2 & 1.00 & 13.7 & 2.26 \\
\hline
\end{tabular}

Note: $\triangle 3$ yrs. $\mathrm{n}=6 ; \triangle 4$ yrs. $\mathrm{n}=4 ; \triangle 5$ yrs. $\mathrm{n}=1 ; \triangle 6$ yrs. $\mathrm{n}=1 / 2 \nabla 2$ yrs. $\mathrm{n}=2$;

$\nabla 3$ yrs. $\mathrm{n}=1 ; \nabla 4$ yrs. $\mathrm{n}=1 ; \nabla 5$ yrs. $\mathrm{n}=1$

the Hottentots and the American Blacks and Whites through almost all the recorded ages, and also between the Rehoboth Basters and both American Whites and Blacks until the ages of about 15 to 17 years in the males and 14 years in the females. Thereafter, however, the Rehoboth Basters and the Americans show few significant differences between them.

On the basis of the TW2 skeletal age, there are a few significant sex differences for both bone length and width in both Hottentots and the related populations. Sex differences are significant only at the age of 9,13 and 16 years for the length in the Rehoboth Basters; and at 11 years in the Hottentots and 16 years in the Rehoboth Basters for the width. In the Japanese, the growth curve of bone length consists of at least two convex curves with a critical point at the ages of approximately 13 years in the males and 11 years in the females. The bone width also shows two convex growth curves with a critical point at the ages of about 12 years in the males and 11 years in the females. Until the critical point is reached, both bone length and width are almost identical in the three populations. In the region of the critical point, however, their rates of increase differ; and these measurements appear greater in the Rehoboth Basters in comparison with the Hottentots after about 9 years for both sexes, and with the Japanese after about 14 years for the males and 11 years for the females.

The index of width/length is generally greater in the males than in the females, significantly at the ages of 9 and 12 years in the Hottentots, and of 14 and 17 years in the Rehoboth Basters, as well as at the TW2 skeletal ages of 7 and 11 years in the former and of 2 and 13 years in the related populations. There are few differences in the index between the Hottentots 
Table 4. Means $(\bar{x})$ and standard deviations (S. D.) of the measurements ( $\mathrm{mm}$ ) of the second metacarpal in the Hottentot children for each skeletal age class.

\begin{tabular}{|c|c|c|c|c|c|c|c|c|c|c|c|c|}
\hline \multirow[b]{2}{*}{ Sex } & \multirow[b]{2}{*}{ Class } & \multirow[b]{2}{*}{$\mathrm{n}$} & \multicolumn{2}{|c|}{ TW2 age } & \multicolumn{2}{|c|}{ Chron. age } & \multicolumn{2}{|c|}{ Length } & \multicolumn{2}{|c|}{ Width } & \multicolumn{2}{|c|}{$\mathrm{W} / \mathrm{L}$} \\
\hline & & & $\overline{\mathrm{x}}$ & S. D. & $\bar{x}$ & S. D. & $\bar{x}$ & S. D. & $\bar{x}$ & S. D. & $\bar{x}$ & S. D. \\
\hline \multirow{13}{*}{$\hat{0}^{\infty}$} & 2 & 1 & 2.1 & - & 3.0 & - & 30.2 & - & 4.8 & & 15.9 & \\
\hline & 4 & 3 & 3.8 & 0.05 & $\triangle 7.0$ & 0.28 & 34.3 & 1.45 & 5.0 & 0.20 & 14.6 & 0.89 \\
\hline & 5 & 1 & 4.6 & - & 7.9 & - & 42.4 & - & 5.5 & - & 13.0 & - \\
\hline & 6 & 4 & 6.1 & 0.35 & 8.4 & 0.90 & 40.1 & 3.41 & 5.1 & 0.69 & 12.7 & 1.98 \\
\hline & 7 & 4 & 7.0 & 0.49 & $\triangle 9.9$ & 0.83 & 42.9 & 3.09 & 6.1 & 0.41 & 14.1 & 0.32 \\
\hline & 8 & 3 & 7.8 & 0.34 & 10.2 & 1.53 & 44.7 & 3.46 & 5.7 & 0.49 & 12.9 & 1.10 \\
\hline & 9 & 10 & 9.2 & 0.20 & 11.0 & 1.63 & 44.7 & 2.31 & 6.0 & 0.70 & 13.4 & 1.70 \\
\hline & 10 & 5 & 10.1 & 0.30 & 11.5 & 1.38 & 46.5 & 2.85 & 6.3 & 0.92 & 13.5 & 1. 27 \\
\hline & 11 & 5 & 10.9 & 0.26 & 12.7 & 1.12 & 48.8 & 3.42 & 7.0 & 0.47 & 14.4 & 0.28 \\
\hline & 12 & 1 & 11.8 & - & 14.7 & - & 53.5 & - & 7.0 & - & 13.1 & - \\
\hline & 13 & 4 & 13.1 & 0.37 & 12.7 & 1.40 & 51.7 & 1.51 & 6.3 & 0.51 & 12.3 & 0.64 \\
\hline & 14 & 3 & 14.3 & 0.35 & 15.7 & 1.43 & 54.4 & 1.76 & 7.0 & 0.85 & 13.0 & 2.01 \\
\hline & 15 & 5 & 15.1 & 0.11 & 15.6 & 1.06 & 57.1 & 3.03 & 7.1 & 0.85 & 12.5 & 1.07 \\
\hline \multirow{12}{*}{$\frac{n}{4}$} & 5 & 2 & 5.1 & 0.42 & 7.5 & 1.13 & 39.7 & 0.21 & 5.0 & 0.07 & 12.5 & 0.14 \\
\hline & 6 & 2 & 6.1 & 0.50 & 8.4 & 1.70 & 40.1 & 2.26 & 5.1 & 0.07 & 13.0 & 0.71 \\
\hline & 7 & 4 & 7.3 & 0.12 & 8.7 & 1.77 & 42.9 & 1.60 & 5.4 & 0.55 & 12.6 & 1. 14 \\
\hline & 8 & 5 & 8.1 & 0.36 & 9.6 & 1.90 & 43.7 & 3.30 & 5.4 & 0.31 & 12.3 & 1.35 \\
\hline & 9 & 12 & 9.1 & 0.24 & $\nabla 10.7$ & 1.40 & $\nabla 46.5$ & 2.91 & $\nabla 6.3$ & 0.81 & $\nabla 13.5$ & 1.74 \\
\hline & 10 & 6 & 9.8 & 0.35 & $\nabla 11.7$ & 1. 11 & $\nabla 48.8$ & 2.84 & $\nabla 6.3$ & 0.54 & $\nabla 12.9$ & 1. 49 \\
\hline & 11 & 6 & 11.0 & 0.25 & 11.7 & 1.16 & 49.5 & 3.11 & 6.1 & 0.38 & 12.4 & 0.73 \\
\hline & 12 & 2 & 12.5 & - & 14.4 & 1. 13 & 49.8 & 3.04 & 6.8 & 1.20 & 13.5 & 1.56 \\
\hline & 13 & 14 & 13.2 & 0.26 & 12.3 & 0.92 & 55.3 & 3.75 & 6.8 & 0.41 & 12.3 & 0.92 \\
\hline & 14 & 5 & 13.9 & 0.26 & 15.7 & 0.65 & 56.2 & 3.09 & 7.0 & 0.43 & 12.5 & 1.33 \\
\hline & 15 & 1 & 15.4 & - & 16.6 & - & 61.1 & - & 6.9 & - & 11.3 & - \\
\hline & 16 & 2 & 16.0 & 0.07 & 16.8 & 0.50 & 60.0 & 0.92 & 7.1 & 1.13 & 11.9 & 2.05 \\
\hline
\end{tabular}

Note: $\triangle 4$ yrs. $\mathrm{n}=2 ; \triangle 7$ yrs. $\mathrm{n}=3$

$\nabla 9$ yrs. $\mathrm{n}=11 ; \nabla 10$ yrs. $\mathrm{n}=5$

and Rehoboth Basters for both sexes. In 13.7 and 12.7 in the Japanese, respectivethe American Whites and Blacks and the ly. The Hottentots and Rehoboth Basters Japanese, the index decreases rapidly as seem to follow a pattern similar to the the age advances until about the age of Americans so as to reach a slightly lower 8 years for both sexes to reach a certain value than the Japanese.

stable state; and thereafter, only in the

Figure 4 shows the relative growth Japanese does it increase again slightly curves of bone width to bone length in to reach a final value. The final value the American Whites and Blacks and the in the recorded ages is about 13 in the Japanese based on the means at each males and 12.3 in the females of the chronological age class, as well as the American Whites and Blacks, as well as regression lines between two measure- 
Table 5. Means $(\bar{x})$ and standard deviations (S. D.) of the measurements ( $m m$ ) of the second metacarpal in the children of Rehoboth Basters for each skeletal age class.

\begin{tabular}{|c|c|c|c|c|c|c|c|c|c|c|c|c|}
\hline \multirow[b]{2}{*}{ Sex } & \multirow[b]{2}{*}{ Class } & \multirow[b]{2}{*}{$\mathrm{n}$} & \multicolumn{2}{|c|}{ TW2 age } & \multicolumn{2}{|c|}{ Chron. age } & \multicolumn{2}{|c|}{ Length } & \multicolumn{2}{|c|}{ Width } & \multicolumn{2}{|c|}{$\mathrm{W} / \mathrm{L}$} \\
\hline & & & $\bar{x}$ & S. D. & $\bar{x}$ & S. D. & $\bar{x}$ & S. D. & $\bar{x}$ & S. D. & $\bar{x}$ & S. D. \\
\hline \multirow{14}{*}{$\hat{0}^{n}$} & 5 & 2 & 5.4 & 0.07 & 7.4 & 0.57 & 45.3 & 7.07 & 5.6 & 0.28 & 12.5 & 1.34 \\
\hline & 6 & 1 & 6.4 & - & 9.0 & - & 42.7 & - & 6.2 & - & 14.5 & - \\
\hline & 7 & 7 & 6.9 & 0.21 & 8.1 & 0.90 & 43.9 & 2.38 & 6.1 & 0.39 & 13.9 & 1.33 \\
\hline & 8 & 5 & 8.0 & 0.33 & 8.6 & 0.89 & 48.6 & 2.46 & 6.7 & 0.85 & 13.8 & 1.76 \\
\hline & 9 & 9 & 9.0 & 0.27 & 9.4 & 1.62 & 46.8 & 1.69 & 6.6 & 0.44 & 14.1 & 1.24 \\
\hline & 10 & 8 & 10.2 & 0.27 & 11.0 & 1.19 & 52.2 & 3.34 & 7.1 & 0.95 & 13.7 & 1.48 \\
\hline & 11 & 6 & 11.0 & 0.30 & 21.1 & 1.82 & 53.5 & 3.72 & 7.4 & 0.71 & 13.8 & 1.37 \\
\hline & 12 & 5 & 12.1 & 0.36 & 12.8 & 2.05 & 54.6 & 2.40 & 7.1 & 0.69 & 13.1 & 1.78 \\
\hline & 13 & 8 & 13.0 & 0.27 & 13.3 & 1.17 & 54.3 & 3.10 & 7.3 & 0.80 & 13.4 & 1.46 \\
\hline & 14 & 6 & 14.1 & 0.28 & 14.5 & 1.38 & 58.8 & 1.70 & 8.0 & 0.29 & 13.5 & 0.66 \\
\hline & 15 & 9 & 15.2 & 0.33 & 15.7 & 1.43 & 63.5 & 5.14 & 8.2 & 0.89 & 13.0 & 1.03 \\
\hline & 16 & 12 & 16.1 & 0.32 & 16.6 & 1.09 & 69.4 & 3.50 & 8.9 & 0.81 & 12.9 & 1.28 \\
\hline & 17 & 6 & 16.8 & 0.14 & 17.3 & 1.03 & 70.5 & 2.83 & 8.7 & 0.57 & 12.4 & 1.24 \\
\hline & 18 & 14 & 17.9 & 0.15 & 18.8 & 1.17 & 69.1 & 3.29 & 9.2 & 0.96 & 13.3 & 1.31 \\
\hline \multirow{11}{*}{$\frac{n}{H}$} & 5 & 1 & 5.5 & - & 8.0 & - & 36.2 & - & 5.0 & - & 13.8 & - \\
\hline & 7 & 5 & 7.1 & 0.39 & 8.8 & 2.10 & 43.7 & 2.05 & 5.8 & 0.72 & 13.4 & 1.53 \\
\hline & 8 & 5 & 8.2 & 0.10 & 8.8 & 1.22 & 47.7 & 3.73 & 6.0 & 0.61 & 12.6 & 1.06 \\
\hline & 9 & 13 & 9.1 & 0.21 & 9.4 & 1.04 & 49.4 & 2.42 & 6.6 & 0.49 & 13.3 & 0.97 \\
\hline & 10 & 8 & 10.0 & 0.31 & $\nabla 11.1$ & 0.67 & $\nabla 51.7$ & 2.64 & $\nabla 7.0$ & 0.69 & $\nabla 13.5$ & 1.57 \\
\hline & 11 & 11 & 11.0 & 0.31 & 11.9 & 1.02 & 52.1 & 3.22 & 6.9 & 0.69 & 13.3 & 1.36 \\
\hline & 12 & 9 & 11.9 & 0.32 & 12.4 & 2.09 & 55.7 & 5.60 & 7.4 & 0.63 & 13.2 & 0.73 \\
\hline & 13 & 14 & 13.2 & 0.23 & 13.3 & 1.09 & 60.2 & 3.72 & 7.3 & 0.56 & 12.2 & 0.93 \\
\hline & 14 & 8 & 13.9 & 0.26 & 13.5 & 1.43 & 61.1 & 3.89 & 7.5 & 0.86 & 12.3 & 1.10 \\
\hline & 15 & 5 & 14.9 & 0.31 & 15.2 & 0.84 & 63.8 & 4.52 & 7.8 & 0.54 & 12.2 & 1.04 \\
\hline & 16 & 17 & 16.0 & 0.10 & 17.1 & 1.00 & 64.1 & 2. 91 & 7.8 & 0.59 & 12.3 & 1.00 \\
\hline
\end{tabular}

Note: $\nabla 10$ yrs. $n=7$

Table 6. Means $(\bar{x})$ and standard deviations (S.D.) of the measurements (mm) of the second metacarpal in the children of Bonnytoun for each skeletal age class.

\begin{tabular}{|c|c|c|c|c|c|c|c|c|c|c|c|c|}
\hline \multirow[b]{2}{*}{ Sex } & \multirow[b]{2}{*}{ Class } & \multirow[b]{2}{*}{$\mathrm{n}$} & \multicolumn{2}{|c|}{ TW2 age } & \multicolumn{2}{|c|}{ Chron. age } & \multicolumn{2}{|c|}{ Length } & \multicolumn{2}{|c|}{ Width } & \multicolumn{2}{|c|}{$\mathrm{W} / \mathrm{L}$} \\
\hline & & & $\bar{x}$ & S. D. & $\bar{x}$ & S. D. & $\bar{x}$ & S. D. & $\bar{x}$ & S. D. & $\bar{x}$ & S. D. \\
\hline \multirow{6}{*}{ 䘾 } & 1 & 1 & 1.2 & - & 2.0 & - & 25.5 & - & 3.7 & - & 14.5 & - \\
\hline & 2 & 7 & 2.1 & 0.17 & 3.0 & 0.37 & 29.8 & 2.62 & 4.6 & 0.44 & 15.6 & 1.50 \\
\hline & 3 & 4 & 2.7 & 0.14 & 3.8 & 0.96 & 31.2 & 0.95 & 4.7 & 0.41 & 15.1 & 1.77 \\
\hline & 4 & 2 & 4.0 & 0.28 & 4.0 & 1.41 & $\triangle 32.9$ & - & $\triangle 5.3$ & - & $\triangle 16.1$ & - \\
\hline & 5 & 2 & 5.0 & - & 4.0 & - & 36.3 & 1.06 & 5.5 & 0.21 & 15.0 & 0.14 \\
\hline & 7 & 1 & 6.6 & - & 6.0 & - & $\triangle$ & & $\triangle$ & & $\triangle$ & \\
\hline \multirow{4}{*}{$\frac{n}{3}$} & 1 & 2 & 1.2 & 0.28 & 1.8 & 0.35 & 26.8 & 1.06 & 4.7 & 0.28 & 17.6 & 1.70 \\
\hline & 2 & 2 & 1.8 & 0.28 & 2.5 & 0.71 & 31.8 & 1.48 & 4.0 & 0.35 & 12.5 & 1.70 \\
\hline & 4 & 1 & 3.6 & - & 5.0 & 一 & 38.7 & - & 6.5 & 一 & 16.8 & - \\
\hline & 5 & 1 & 4.6 & - & 4.0 & - & 35.5 & - & 4.8 & - & 13.5 & - \\
\hline
\end{tabular}

Note; $\triangle 4$ yrs. $n=1 ; \triangle 7$ yrs. $n=0$ 


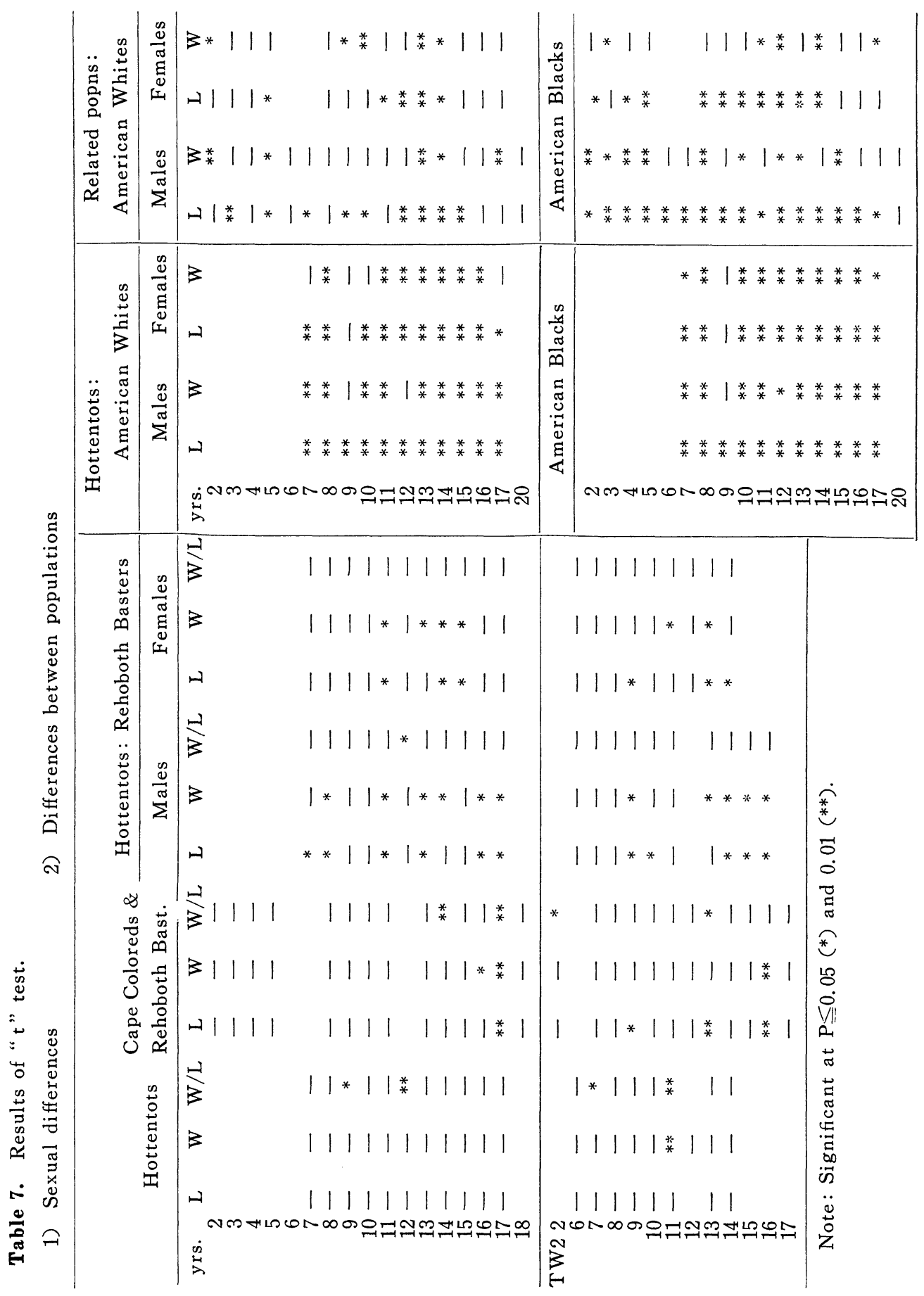



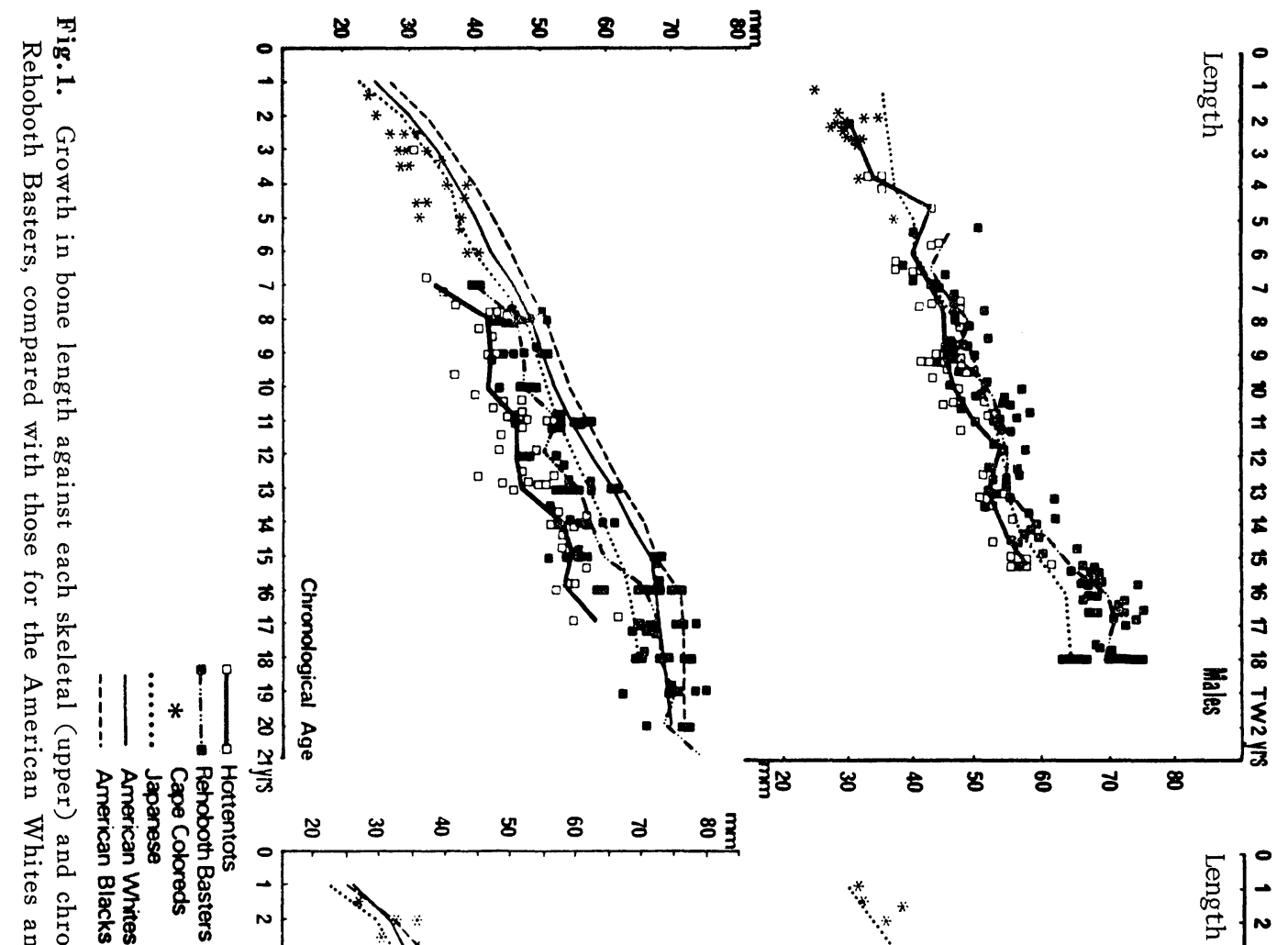

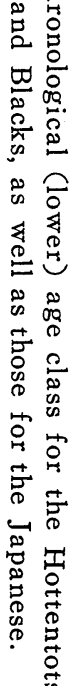
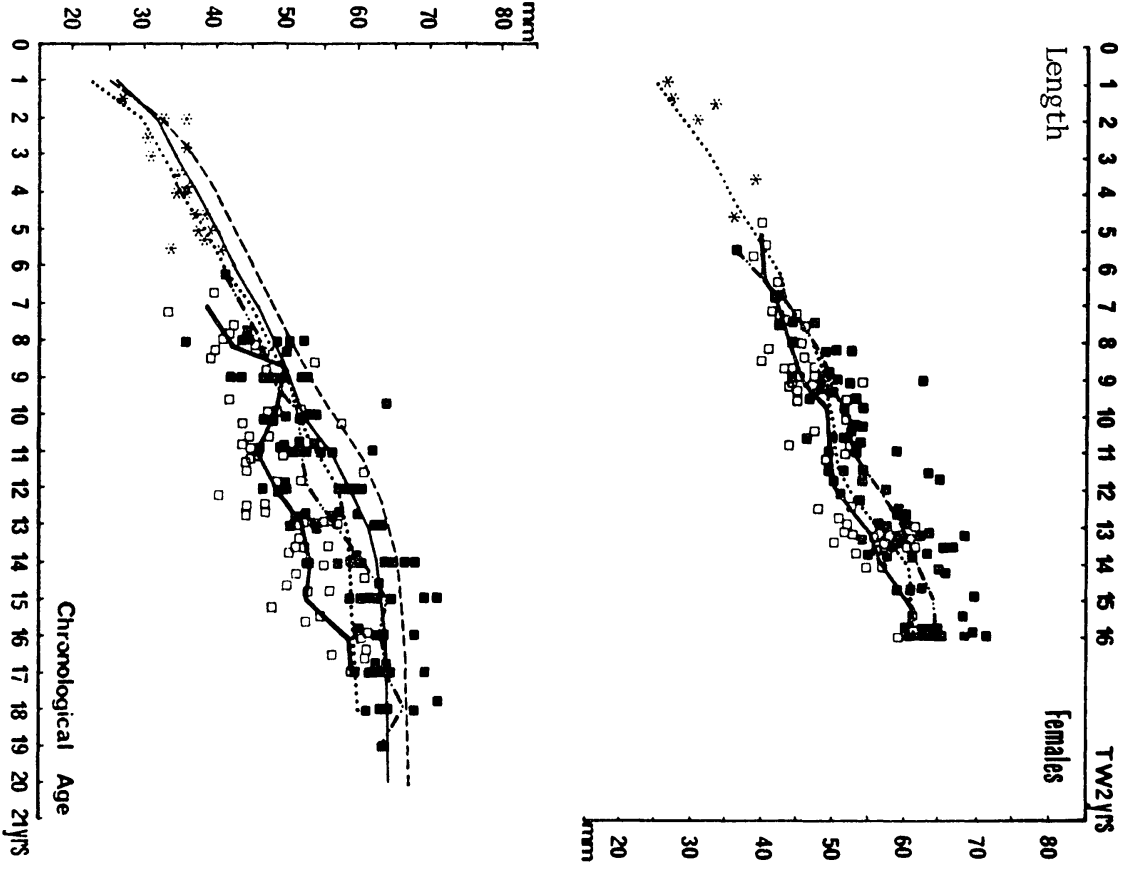


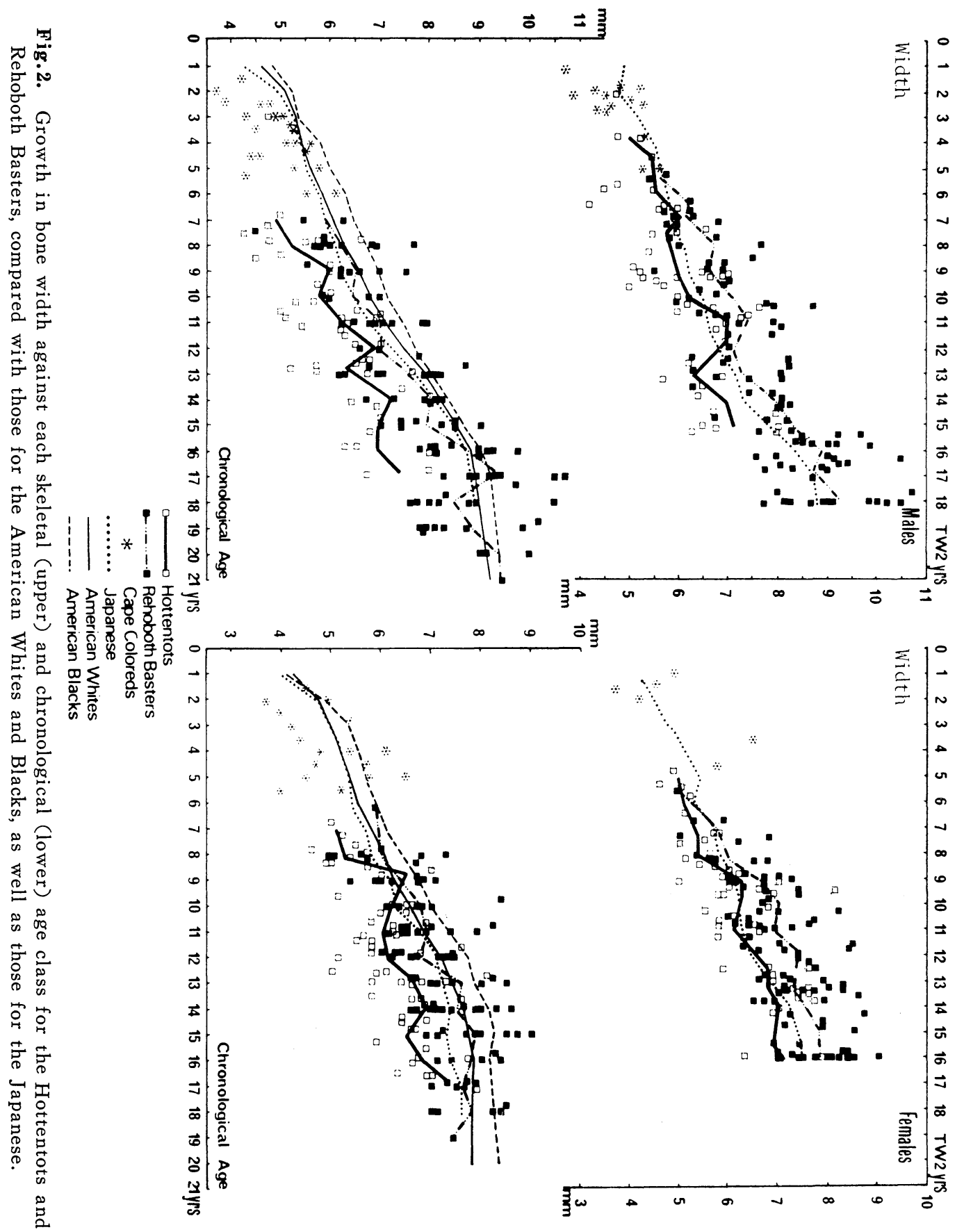




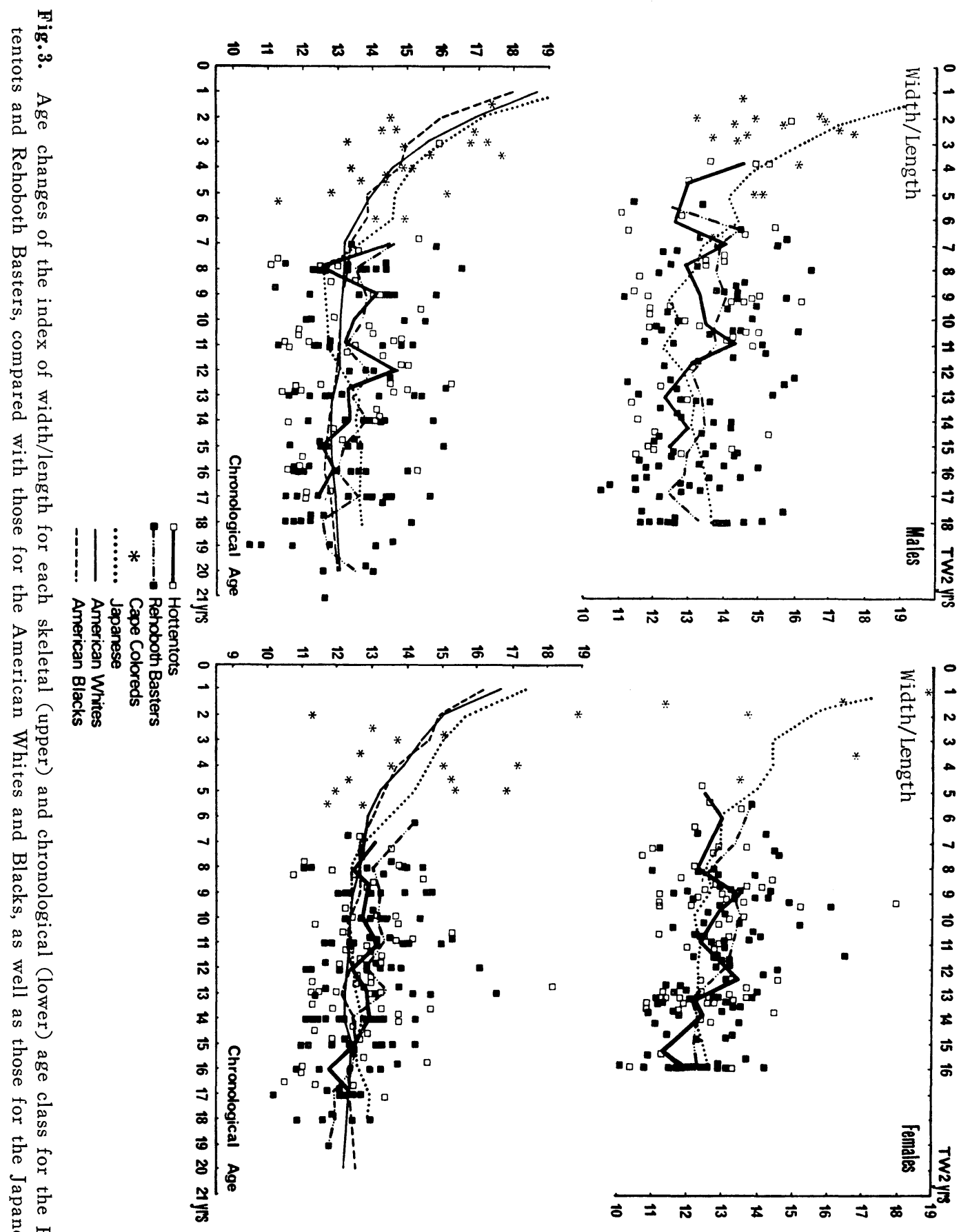


ments in the Hottentots and Rehoboth Basters based on all individuals whose bone lengths are $40 \mathrm{~mm}$ and over. The relative growth curve consists of three periods with two critical points. The first one occurs at about $40 \mathrm{~mm}$ bone length, though the second varies with sex in each population. The regression lines are parallel to each other in the Hottentots and Rehoboth Basters for both sexes, with the line for the Rehoboth Basters at a higher level. The equation of regression is as follows :

Hottentots :

$y=0.1054 x+1.2825$ for the males $y=0.0847 x+2.0750$ for the females

Rehoboth Basters :

$y=0.1076 x+1.4759$ for the males $y=0.0850 x+2.3494$ for the females ( $x=$ bone length: $y=$ bone width). The regression line of the Hottentots seems to approximate the relative growth curves of the Americans and Japanese. The second critical point occurs somewhat earlier in the Japanese than in both the American groups. Because of the small sample size, however, the second critical points are unknown in both Hottentots and Rehoboth Basters. At complete maturity (Fig. 4), the Hottentots, as well as their related populations, seem to be similar to the American Blacks and Whites, but lower than the Japanese.

The differences and similarities between the populations evaluated cannot be argued on a simple nature vs. nurture basis, even though it is known that, of the African groups, the nutritional status of the Hottentot children is lowest while that of the Bonnytoun children may be equal to or slightly better than that of the Rehoboth children. Real comparisons of the nutritional status of the African children cannot be made with that of the American White and Black and Japanese children.

\section{ACKNOWLEDGEMENTS}

Field research (for R.S.)was supported, in part, by USPHS grants RG 7297 (Sl) and GM 10113, the Wenner-Gren Foundation for Anthropological Research, Inc. and many private donors. Support was also received (by R.S.) from the Louis Block Fund, University of Chicago. We are especially grateful to Dr. B. Hirschson (Cape Town) and the late Dr. Nels Strandjord (Chicago) who helped to overcome many difficulties to obtain good radiographs in the field. Field collaborators included Professors J.S. WeIneR (London) and G. A. Harrison (Oxford) and Dr. W. JopP (Wiesbaden).

\section{REFERENCES}

Garn, S.M., Miller, R.L. and Larson, K., 1972: Metacarpal lengths, cortical diameters and areas from the 10-state nutrition survey, including: estimated skeletal weights, weight, and stature for Whites, Blacks, and Mexican-Americans. In "Ten-State Nutrition Survey 1968-1970". Atlanta, U.S. Department of Health, Education, and Welfare, Center for Disease Control, publication No. (HSM) 72-8130.

Heltne, P. G. and Singer, R. 1971: Cytogenetic studies in the Hottentot population: count distribution, report of a fragment and preliminary description of morphology. Am. J. Phys. Anthrop., 34: 1-34.

Himes, J.H. and Malina, R.M. 1977: Sexual 


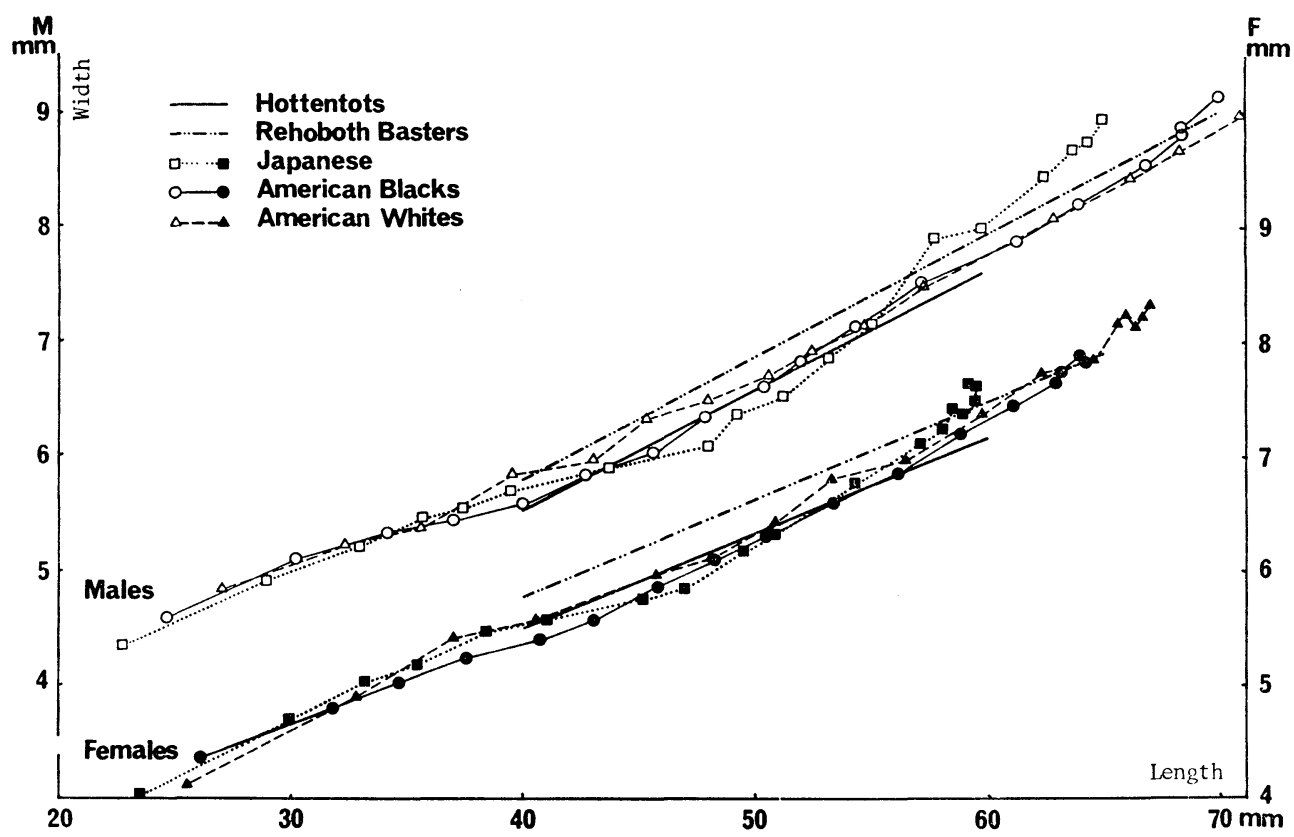

Fig.4. Relative growth curves of bone width to bone length in the American Whites and Blacks and the Japanese based on the means at each chronologiccal age class, as well as the regression lines between two measurements in the Hottentots and Rehoboth Basters on all individuals whose bone lengths are $40 \mathrm{~mm}$ and over.

dimorphism in metacarpal dimensions and body size of Mexican school children. Acta anat., 99: 15-20.

Himes, J.H., Malina, R.M. and Stepick, C. D., 1976: Relationships between body size and second metacarpal dimensions in Oaxaca (Mexico) school children 6 to 14 years of age. Hum. Biol., 48: 677-692.

Himes, J.H., Martorell, R., Habicht, J. -P., Yarbrough, C., Malina, R.M. and Klein, R.E., 1970: Sexual dimorphism in bone growth as a function of body size in moderately malnourished Guatemalan preschoolage children. Am. J.Phys. Anthrop., 45: 331336.

KimurA, K., 1976: Growth of the second metacarpal according to chronological age and skeletal maturation. Anat. Rec., 184 : 147-158.

KimurA, K., 1977: Growth of the second metacarpal based on skeletal maturity. J. Natl. Def. Med. Coll., 2: 27-31.
KimurA, K. and Singer, S., 1979: Growth of body height and weight and skeletal matu. ration in Hottentot children. Fourth International Symposium on the Morphological Sciences, at Toledo, U.S. A.

KRUt, L.H. and Singer, R., 1963: Steatopygia : the fatty acid composition of subcutaneous adipose tissue in the Hottentot. Am. J. Phy. Anthrop., 2: 181-188.

Maresh, M.M., 1961: Bone, muscle and fat measurements. Longitudinal measurements of the bone, muscle and fat widths from roentgenograms of the extremities during the first six years of life. Pediatrics, 28: 971-984.

MAzess, R. B. and CAmeron, J. R., 1971: Skeletal growth in school children: maturation and bone mass. Am. J. Phys. Anthrop., 35: 399-407.

Owen, G.M., Filer, L. J., Maresh, M. and Fomon, S.J., 1966: Sex-related differences 
in body composition in infancy. In "Human development" (F. Falkner, ed.): 246-253. Saunders Co., Philadelphia.

REynoldS, E. L., 1944: Differential tissue growth in the leg during childhood. Child Dev., 15: 181-205.

SINGER, R., 1970: Investigations of the biology of Hottentot and Bushman populations in Southern Africa. Materialy i Prace Anthropologiczne, Warsaw (Polish Academy of Sciences: Proceedings of the HA/IBP Symposium-Man in Africa): 37-48.

Singer, R. and Gajisin, S.M., 1974: Carpal growth changes in Hottentot children. Am. J. Phys. Anthrop., 41: 503 (Abstract).

Singer, R., Kimura, K. and Gajisin, S. M., 1980: Brachymesophalangia V in Hottentot and "Cape Colored" children in Namibia (South West Africa) and South Africa. Am.
J. Phys. Anthrop., 52: 533-539.

Singer, R. and Weiner, J., 1963: Biological aspects of some indigenous African populations. Southwest. J. Anthrop., 19: 168-176.

Tanner, J.M., Whitehouse, R.H., MarSHALl, W. A., HEALY, W.J.R. and GolDSTEIN, H., 1975: Assessment of skeletal maturity and prediction of adult height (TW2 method). Academic Press, London and New York.

Weiner, J., Harrison, G. A., Singer, R., HARRIS, R. and JopP, W., 1964: Skin colour in Southern Africa. Hum. Boil., 36: 294-307.

WolAŃSKI, N., 1967 : Changes in bone density and cortical thickness of the second metacarpal between the ages of 3 and 74 years as a method for investigating bone mineral metabolism. Acta anat. 67: 74-94.

(Received May 8, 1980)

\title{
ホッテントットの第二中手骨の成長
}

\author{
Ronald SINGER \\ 木 村 邦 彦 \\ 1) Department of Anatomy, The University of Chicago \\ 1) 防衛医科大学校解剖学第二講座
}

ナミビアの 3 ～17歳の男 49 名, 女61名のホッテントットと, 白人との混血であるナミビアのレオボス・バス ターと南アフリカのケープ・カラードの $1 \sim 21$ 歳の男 124 名, 女 113 名の, 手のX線像から計測された第二中 手骨の長・幅径と長幅指数について, 暦年齢と TW2 骨格年齢とから成長が論じられた。成績は主にアメリカ 黒人と白人, そして日本人の結果と比較された。骨格年齢によると, ある臨界期に達するまでは, 中手骨の長 ・幅径はこれらの集団間で差がない。臨界点から増加率に差が見られ, 以後, 両測度はホッテントットと日本 人よりあレオボス・バスターでより大きい。しかし, 成熟時の中手骨の長幅指数では, ホッテントットとその 混血集団はアメリカ黒人と白人に似て，日本人よりはわずかに小さいと思われる。 